\title{
Use of Landscape-level River Signatures in Conservation Planning: a South African Case Study
}

\author{
$\underline{\text { Dirk Roux }}^{1}, \underline{\text { Ferdy de Moor }}^{2}$, Jim Cambray $^{2}$, and Helen Barber-James $^{2}$
}

\begin{abstract}
A strategy for assigning priorities in biodiversity conservation was developed for the rivers of the proposed Greater Addo Elephant National Park (GAENP) in South Africa. Due to the limited availability of biological information on the freshwater ecosystems of this area, a desktop approach, supplemented by aerial and land surveys, was used to devise a new river classification typology. This typology incorporated landscape attributes as surrogates for biodiversity patterns, resulting in defined physical "signatures" for each river type. Riverine biodiversity is considered to be conserved by including rivers of each type as defined by the respective signatures. Where options existed, and two or more rivers shared the same signature, a simple procedure was used to assign priorities to "similar" rivers for conservation. This procedure considered the extent of transformation, degree of inclusion within the park, irreplaceability or uniqueness, and geomorphological diversity of each river. The outcome of the study was that 18 of the 31 rivers within the GAENP must be conserved to achieve representation of all of the biodiversity patterns identified. It is concluded that, given further development and testing, the river signature concept holds promise for elevating the river focus in general conservation planning exercises.
\end{abstract}

\section{INTRODUCTION}

The Addo Elephant National Park was proclaimed in 1931 to protect the last remaining elephants in the Eastern Cape Province of South Africa. Since proclamation, the park has been enlarged at irregular intervals to cope with the ever increasing numbers of elephants. A vision for the comprehensive expansion of the current park was expressed in a proposal by Kerley and Boshoff (1997). This proposal gave rise to the current Greater Addo Elephant National Park Conservation Planning and Development Project. The overall aim of this project is to conserve biodiversity and stimulate sustainable development in the region.

The project consists of three modules for terrestrial and aquatic conservation planning, strategic environmental assessment, and socioeconomic and institutional assessments. The goal of the first module was to identify options for establishing an expanded park within the planning domain that would conserve representative and viable biodiversity patterns and underlying processes. This module was divided into terrestrial, marine-estuarine, and freshwater subcomponents. The outputs of the three subcomponent studies had to be compatible to allow for the development of a single, integrated conservation plan for the Greater Addo Elephant National Park (GAENP). The planning tool adopted for the GAENP conservation study, namely $C$-plan decision-support software (Ferrier et al. 2000), provided the framework for the subcomponent studies and dictated to a large degree the types and formats of the information to be produced by each study.

C-plan was essentially developed around the wellestablished process of systematic conservation planning (Margules and Pressey 2000). The application of this process is much further advanced for terrestrial ecosystems than for aquatic ecosystems. Although river ecologists have developed sufficient knowledge to conceptually structure biodiversity patterns at the river landscape scale (Ward 1998), the application of this knowledge in the process of systematic conservation planning has received relatively limited attention (Poiani et al. 2000). Previous studies included aquatic systems primarily to serve terrestrial conservation targets. For example, river corridors may be selected as an essential spatial component for the purpose of linking inland basins with coastal plains to allow migration and exchange between inland and coastal biota (Cowling and Pressey 
2001). The challenge for the GAENP freshwater study was to elevate the weight of freshwater biodiversity features so that these could contribute to the planning process as well-defined and independent components of the overall biodiversity pattern.

The brief for the freshwater component of the study was to evaluate and consolidate current biodiversity information on the freshwater ecosystems to contribute to the drafting of an overall conservation plan for the GAENP. Biological information on the freshwater ecosystems within the GAENP is extremely limited. For this reason, the study focused largely on the physical habitat templates of these ecosystems. Spatial data for wetland types (lentic ecosystems) were virtually nonexistent. Consequently, a systematic conservation planning procedure was developed for riverine or lotic ecosystems only.

The approach that was developed for conserving the riverine ecosystems of the GAENP followed the steps that were adopted for the overall conservation planning process. This paper outlines the steps that were key to the freshwater approach, namely to:

- delineate biodiversity patterns for rivers and streams,

- identify the ecosystem processes that maintain biodiversity,

- set quantitative targets for conserving biodiversity, and

- assign priorities to the options available for achieving conservation targets.

\section{STUDY AREA AND INFORMATION SOURCES}

\section{Study area}

The area that has been demarcated for this study is approximately 1,000,000 ha in the southeastern part of South Africa (Fig. 1) and is referred to as the Greater Addo Elephant National Park (GAENP) planning domain. The landscape diversity of the GAENP is exceptional and includes examples of five of the seven biomes (areas with relatively homogenous climate and vegetation) that occur in southern Africa (Rutherford and Westfall 1994). The inland parts in the northwest are mostly dry with succulent and sparse vegetation, and are separated from the coastal planes and dunes in the southeast by the Zuurberg Mountains. Rainfall increases toward the south and east.
The most significant river system that flows though the GAENP is the Sundays River and its tributaries. Darlington Dam is the largest man-made impoundment in the planning domain, and the flow of the Sundays River below the dam is regulated. Other important river systems are the upper Bushmans River and its tributaries, the Blou and Steins Rivers in the northeast, and the Boknes River and its tributaries in the southeast. The Sundays and Boknes Rivers flow into the Indian Ocean.

\section{Information sources}

A one-day aerial survey by fixed-wing aircraft and a three-day land survey of the planning domain contributed significantly to our general orientation and knowledge regarding the rivers of the GAENP. Other than the data obtained by these surveys, the freshwater study was restricted to the desktop evaluation of existing information. The most useful information sources were GIS data layers, including land use and land cover (CSIR; 1:250 000; vector, polygon), areas invaded by alien plants (CSIR; vector, polygon), elevation (Surveyor General; 100-m intervals; raster, grid), geological formations (Council for Geoscience; 1:250 000; vector, polygon), rainfall classes (Computing Center for Water Research and CSIR; 1 minute; raster, grid), and rivers and streams (Department of Water Affairs and Forestry; 1:50 000; vector, line).

\section{BIODIVERSITY PATTERNS}

Due to the shortage of available biological information at the species, population, and community levels, landscape and ecosystem parameters were used as surrogates for overall biodiversity patterns for the purposes of this study. River ecosystems are essentially a manifestation of the landscapes that they drain. Catchment geology, climate, vegetation types, and landscape change dictate the character of freshwater ecosystems in terms of flow pattern, channel morphology, temperature and nutrient regimes, and substratum. These variables in turn control the biological attributes of rivers and streams (Stanford 1998). Stream biota are therefore considered to be protected by conserving habitat heterogeneity or pattern.

A multilevel hierarchical approach was followed for the delineation of habitat pattern, providing an increasing resolution to locate types of similar riverine ecosystems. The principle is that rivers grouped 
together at a particular level of the hierarchy will be more similar to one another than to rivers in other groups at the same hierarchical level. The three levels of the delineation hierarchy used are river flow patterns, ecoregions as a measure of landscape patterns, and geomorphological zones as a measure of longitudinal patterns of rivers. The approach to typology within each of these levels is briefly described below.

Fig. 1. Locality of the study area or planning domain for the proposed Greater Addo Elephant National Park with boundaries of the relevant ecoregions. Broad characteristics of these ecoregions are given in Table 1.

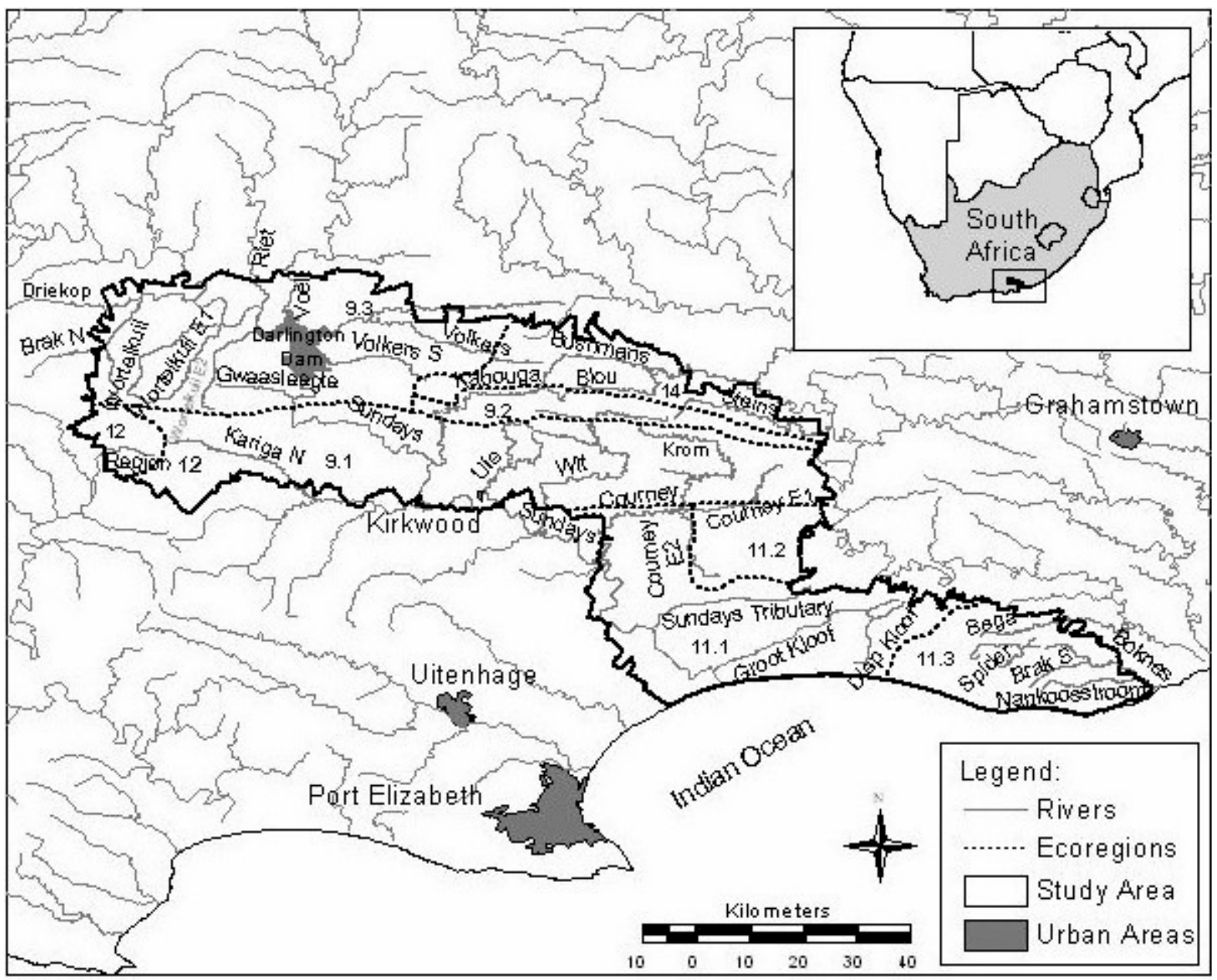

\section{Level 1: River flow patterns}

Perennial, seasonal, ephemeral, and episodic rivers were considered as different ecosystem types. The rationale behind this level of delineation was that each of the flow types gives rise to a distinct complement of biotopes that provide habitat for specific groupings of flora and fauna. The distinction was based on perennial, intermittent, and ephemeral flow regimes as defined by Gordon et al. (1992) and Ward (1975). However, the intermittent flow type was split into seasonal (more predictable) and episodic (less predictable) flows to cater specifically for the rivers of the Greater Addo Elephant National Park (GAENP). The different types of rivers are defined as follows.

- Perennial rivers have surface flow throughout the year and do not cease to flow even during droughts.

- Seasonal rivers flow predictably during the annual wet season but may be dry for several months each year.

- Episodic (periodic or intermittent) rivers flow for an extended period but are not predictable or seasonal. These rivers usually have flow contribution from rainfall as well as 
groundwater. At times, surface flow may occur in some segments only, with subsurface flow in other segments. The fauna here can differ considerably depending on the duration of flow, colonization succession of different species, proximity of other water sources, and extent of time during which previous flow occurred.
- Ephemeral (short-lived) rivers flow briefly and rarely and return to dry conditions in between. Their flow is usually sourced entirely from precipitation. Only aquatic biota able to complete their life cycles very rapidly (within a few days) are able to exploit such flow conditions.

Table 1. Characteristics of the Level 2 ecoregions within the Greater Addo Elephant National Park (GAENP) planning domain.

\begin{tabular}{|c|c|c|c|c|c|}
\hline \multirow[b]{2}{*}{$\begin{array}{l}\text { Ecore } \\
\text { gion }\end{array}$} & \multirow[b]{2}{*}{$\begin{array}{l}\text { Predominant } \\
\text { lithology }\end{array}$} & \multicolumn{2}{|c|}{ Most prominent vegetation types } & \multirow[b]{2}{*}{$\begin{array}{l}\text { Annual } \\
\text { rainfall } \\
\text { (50-mm } \\
\text { classes) }\end{array}$} & \multirow[b]{2}{*}{$\begin{array}{l}\text { Elevation } \\
\text { (100-m } \\
\text { intervals) }\end{array}$} \\
\hline & & $\begin{array}{c}\text { after Low } \\
\text { and Rebelo (1996) }\end{array}$ & $\begin{array}{l}\text { after GAENP } \\
\text { mapping exercise }\end{array}$ & & \\
\hline 9.1 & $\begin{array}{c}\text { Calcareous } \\
\text { sandstone, } \\
\text { sandstone, shale }\end{array}$ & $\begin{array}{l}\text { Xeric succulent thicket, grassy } \\
\text { fynbos, clusters of Afromontane } \\
\text { forest }\end{array}$ & $\begin{array}{l}\text { Bontveld, thicket (various), } \\
\text { Zuurberg proteoid fynbos }\end{array}$ & $150-550$ & $200-900$ \\
\hline 9.2 & $\begin{array}{c}\text { Calcareous } \\
\text { sandstone, } \\
\text { sandstone, shale }\end{array}$ & $\begin{array}{c}\text { Xeric succulent thicket, grassy } \\
\text { fynbos, clusters of Afromontane } \\
\text { forest }\end{array}$ & $\begin{array}{l}\text { Grassy fynbos, shrubby } \\
\text { grassland, sour grassland, } \\
\text { Noorsveld, thicket, broken veld }\end{array}$ & $200-500$ & $600-900$ \\
\hline 9.3 & $\begin{array}{c}\text { Calcareous } \\
\text { sandstone, } \\
\text { sandstone, shale }\end{array}$ & $\begin{array}{c}\text { Xeric succulent thicket, eastern } \\
\text { mixed Nama Karoo, valley } \\
\text { thicket }\end{array}$ & $\begin{array}{l}\text { Noorsveld, Spekboomveld, } \\
\text { thicket, broken veld }\end{array}$ & $50-250$ & $200-600$ \\
\hline 11.1 & $\begin{array}{l}\text { Calcareous } \\
\text { sandstone, } \\
\text { sandstone, silt }\end{array}$ & $\begin{array}{l}\text { Mesic succulent thicket, xeric } \\
\text { succulent thicket }\end{array}$ & $\begin{array}{l}\text { Forest, Bontveld, Strandveld, } \\
\text { Spekboomveld, Dunefield }\end{array}$ & $200-450$ & $0-400$ \\
\hline 11.2 & $\begin{array}{l}\text { Calcareous } \\
\text { sandstone, } \\
\text { shale, tuff, } \\
\text { sandstone }\end{array}$ & $\begin{array}{c}\text { Eastern thorn, Bushveld, mesic } \\
\text { succulent thicket }\end{array}$ & $\begin{array}{l}\text { Bontveld, Strandveld, } \\
\text { Spekboomveld }\end{array}$ & $200-450$ & $0-400$ \\
\hline 11.3 & $\begin{array}{l}\text { Calcareous } \\
\text { sandstone, } \\
\text { shale }\end{array}$ & $\begin{array}{l}\text { Coastal forest, eastern thorn } \\
\text { bushveld, coastal grassland, } \\
\text { dune thicket, valley thicket }\end{array}$ & $\begin{array}{l}\text { Forest, Bontveld (various), } \\
\text { thicket, dunefield }\end{array}$ & $400-900$ & $0-400$ \\
\hline 12 & $\begin{array}{c}\text { Calcareous } \\
\text { sandstone, } \\
\text { sandstone, shale }\end{array}$ & $\begin{array}{l}\text { Central lower Karoo, Spekboom } \\
\text { succulent thicket, grassy fynbos }\end{array}$ & Bontveld, Pentziaveld & $150-250$ & $500-800$ \\
\hline 14 & Sandstone, shale & $\begin{array}{l}\text { Eastern mixed Nama Karoo, } \\
\text { xeric succulent thicket }\end{array}$ & $\begin{array}{c}\text { Noorsveld, Bontveld, } \\
\text { Spekboomveld, broken veld, } \\
\text { Pentziaveld }\end{array}$ & $200-350$ & $400-800$ \\
\hline
\end{tabular}




\section{Level 2: Ecoregions as a measure of landscape patterns}

Omernik (1987) developed the ecoregion concept for the United States. The typology of ecoregions is a hierarchical procedure involving the delineation of spatial units with a progressive increase in detail at each higher level of the hierarchy. Freshwater ecosystems that are grouped together within an ecoregion at any level of the hierarchy will be more similar to each other than to systems in other ecoregions at the same level of the hierarchy.

In South Africa, physiography, climate, geology and soils, and potential natural vegetation have been used as the primary delineators of ecoregions at the first hierarchical level, i.e., Level 1 ecoregions. Level 1 ecoregional typology has been done for the whole of South Africa, resulting in 18 defined regions (Department of Water Affairs and Forestry 1999).

Four of these Level 1 ecoregions are relevant to the GAENP project, namely:

- Ecoregion 9: the Eastern Uplands (central and northeastern parts of the planning domain),

- Ecoregion 11: the Southern Coastal Belt (southern half of the planning domain),

- Ecoregion 12: the Cape Folded Mountains (only small southern corner of the easternmost part of the planning domain), and

- Ecoregion 14: Nama Karoo (relatively small section in the northwestern part of the planning domain).

To allow a higher resolution of assessment, Level 1 ecoregions were refined to Level 2 ecoregions. Primary considerations for delineating the Level 2 ecoregion boundaries were variations in geology, natural vegetation (Low and Rebelo 1996), and altitude as well as knowledge of the rivers that flow through the planning domain. Land classes that were delineated during a high-resolution field mapping exercise carried out as part of the terrestrial component of the GAENP conservation study were used to refine both Level 1 and Level 2 boundaries.

Figure 1 indicates the Level 1 and Level 2 ecoregions that were delineated for the GAENP. The characteristics of each of these ecoregions are summarized in Table 1.

\section{Level 3: Geomorphological zones as a measure of longitudinal patterns}

Rowntree and Wadeson (2000) proposed a geomorphological model to classify rivers and streams as a further breakdown within the ecoregional template. The hierarchical structure of the geomorphological model covers catchments, segments, geomorphological zones, reaches, morphological units, and hydraulic biotopes, each with a specific definition.

For the GAENP study, it was decided to make use of a modified geomorphological zonation after Rowntree and Wadeson (2000) to distinguish between mountain headwaters, upper foothills, lower foothills, lowland rivers, and rejuvenated zones (Table 2). River profiles were derived from the GIS coverage for rivers, and the gradient classes shown in Table 2, together with expert judgment, were used to identify the geomorphological zones for each river.

The configuration of these zones in each river is a reflection of regional geological events and long-term fluvial action. For rivers, these geomorphological zones represent different physical templates for biotic habitation. The classic longitudinal profile shows a downstream decrease in slope gradient that leads to decreased velocity of water, resulting in gradual changes in bed and bank material size, i.e., from large or coarse in the upper reaches to fine and silty in the lower gradient zones.

\section{Signatures of physical patterns}

Information on the flow pattern of rivers, ecoregions, and geomorphological zones was used to construct "signatures of physical pattern" for the rivers in the GAENP. Signatures were constructed by summarizing the outcome of each of the three hierarchical typing levels for each river, i.e., flow pattern, ecoregion, and geomorphological zone. As an example, the Wit River is perennial, flows through Ecoregions 9.2 and 9.1 (in that order), and contains mountain headwaters (A), upper foothills (B), lower foothills (C), and a rejuvenated section (R). Consequently, the Level 3 signature for the Wit River is Per-9.2/9.1-A, B, C, R. Rivers that share exactly the same signature would be regarded as rivers that share the same biodiversity pattern, at least at the level of resolution offered by incorporating the three levels of the typology. 
Table 2. The geomorphological zonation of river channels that was used to distinguish between mountain headwaters, upper foothills, lower foothills, lowland rivers, and rejuvenated zones (modified after Rowntree and Wadeson 2000).

\begin{tabular}{lll}
\hline Longitudinal & Gradient & Characteristic channel features \\
zone (code)
\end{tabular}

\begin{tabular}{|c|c|c|}
\hline $\begin{array}{l}\text { Mountain } \\
\text { headwater stream (A) }\end{array}$ & $>0.04$ & $\begin{array}{l}\text { Steep to very steep gradient streams characterized by } \\
\text { waterfalls, plunge pools, bedrock fall, cascades, and step-pools. } \\
\text { Bottom substrate dominated by bedrock, boulders, and cobble } \\
\text { or coarse gravel in pools. }\end{array}$ \\
\hline Upper foothills (B) & $0.005-0.019$ & $\begin{array}{l}\text { Moderately steep, cobble bed or mixed bedrock-cobble bed } \\
\text { channel, with plane bed, pool-riffle, or pool-rapid reach types. } \\
\text { Length of pools and riffles/rapids similar. Narrow floodplain of } \\
\text { sand, gravel, or cobble often present. }\end{array}$ \\
\hline Lower foothills (C) & $0.001-0.005$ & $\begin{array}{l}\text { Lower-gradient mixed-bed alluvial channel with sand and } \\
\text { gravel dominating the bed, locally may be bedrock-controlled. } \\
\text { Reach types typically include pool-riffle or pool-rapid with } \\
\text { sand bars common in pools. Pools of significantly greater } \\
\text { extent than rapids or riffles. Floodplain often present. }\end{array}$ \\
\hline Lowland river (D) & $0.0001-0.001$ & $\begin{array}{l}\text { Lower-gradient alluvial fine-bed channel, typically regime } \\
\text { reach type. May be confined, but fully developed meandering } \\
\text { pattern within a distinct floodplain develops in unconfined } \\
\text { reaches where there is an increased silt content in bed or banks. }\end{array}$ \\
\hline $\begin{array}{l}\text { Rejuvenated bedrock/ } \\
\text { foothills }(\mathrm{R})\end{array}$ & $>0.02$ & $\begin{array}{l}\text { Moderate to steep gradient, often confined channel (gorge) } \\
\text { resulting from uplift in middle to lower reaches of the long } \\
\text { profile, limited lateral development of alluvial features, reach } \\
\text { types include bedrock fall, cascades, and pool-rapid. }\end{array}$ \\
\hline
\end{tabular}

At the first level, all the rivers that share a particular flow pattern represent one signature or biodiversity pattern. Typing at the first level gives rise to four distinct signatures. At the second level, all the rivers with a particular flow pattern that flow through the same ecoregion represent a more refined signature or biodiversity pattern. Sixteen unique Level 2 signatures were identified. At the third level, rivers with a particular flow pattern that flow through the same ecoregion and display the same geomorphological characteristics represent an even more refined signature or biodiversity pattern. Thirty-one unique Level 3 signatures were identified.

The signature concept can potentially be extended to incorporate additional physical features of rivers, e.g., lateral patterns such as riparian and floodplain characteristics. The appropriate level of signature would depend on the level of resolution required for a specific study as well as the availability of the different types of data. For the GAENP study, Level 2 signatures were used to reflect habitat heterogeneity and to act as a surrogate for biodiversity pattern in the planning process (Table 3). However, the geomorphological characteristics used to construct Level 3 signatures were retained and used to assign priorities to the available options for achieving the conservation targets.

\section{ECOSYSTEM PROCESSES}

In addition to identifying biodiversity patterns, ecosystem processes that maintain genetic diversity and promote diversification must be considered and represented in the conservation plan. This is necessary to maintain natural disturbance regimes, migratory 
corridors, habitat diversity, landscape connectivity, 2001). and evolutionary templates (Cowling and Pressey

Table 3. Level 2 signatures of physical pattern for rivers and streams of the Greater Addo Elephant National Park. River names in italics were assigned for the purposes of this study because no official names for these rivers could be found.

\begin{tabular}{|c|c|c|c|c|}
\hline River name & Ecosystem type & Ecoregion & $\begin{array}{l}\text { Level } 2 \\
\text { signature }\end{array}$ & $\begin{array}{l}\text { Number of unique } \\
\text { Level } 2 \text { signature }\end{array}$ \\
\hline Wortelkuil & Ephemeral & 9.3 & Eph-9.3 & 1 \\
\hline Wortelkuil E1 & Ephemeral & 9.3 & Eph-9.3 & \\
\hline Wortelkuil E2 & Ephemeral & 9.3 & Eph-9.3 & \\
\hline Gwaasleegte & Ephemeral & 9.3 & Eph-9.3 & \\
\hline Driekop & Ephemeral & 9.3 & Eph-9.3 & \\
\hline Voël & Ephemeral & 9.3 & Eph-9.3 & \\
\hline Brak N. & Ephemeral & 9.3 & Eph-9.3 & \\
\hline Riet & Ephemeral & 9.3 & Eph-9.3 & \\
\hline Volkers & Ephemeral & $14 / 9.3$ & Eph-14/9.3 & 2 \\
\hline Volkers $S$ & Ephemeral & $14 / 9.3$ & Eph-14/9.3 & \\
\hline Bushmans & Ephemeral & 14 & Eph-14 & 3 \\
\hline Blou & Ephemeral & $9.2 / 14$ & Eph-9.2/14 & 4 \\
\hline Steins & Seasonal & $9.2 / 14$ & Se-92./14 & 5 \\
\hline Region 12 & Episodic & 12 & Ep-12 & 6 \\
\hline Kariega N. & Episodic & 9.1 & Ep-9.1 & 7 \\
\hline Uie & Episodic & 9.1 & Еp-9.1 & \\
\hline Krom & Perennial & 9.1 & Per-9.1 & 8 \\
\hline Kabouga & Episodic & $9.2 / 9.1$ & Ep-9.2/9.1 & 9 \\
\hline $\begin{array}{l}\text { Wit (including Wit } \\
\text { W1 and Wit W2) }\end{array}$ & Perennial & $9.2 / 9.1$ & Per-9.2/9.1 & 10 \\
\hline Courney & Perennial & $9.1 / 11.1$ & Per-9.1/11.1 & 11 \\
\hline
\end{tabular}




\begin{tabular}{|c|c|c|c|}
\hline Courney E1 & Seasonal & $11.2 / 11.1$ & Se-11.2/11.1 \\
\hline Courney E2 & Seasonal & $11.2 / 11.1$ & Se-11.2/11.1 \\
\hline Sundays & Perennial & $9.3 / 9.1 / 11.1$ & Per-9.3/9.1/11.1 \\
\hline Sundays Trib & Seasonal & 11.1 & Se-11.1 \\
\hline Groot Kloof & Seasonal & 11.1 & Se-11.1 \\
\hline Diep Kloof & Seasonal & 11.1 & Se-11.1 \\
\hline Boknes & Perennial & 11.3 & Per-11.3 \\
\hline Bega & Seasonal & 11.3 & Se-11.3 \\
\hline Brak S. & Seasonal & 11.3 & Se-11.3 \\
\hline Nankoostroom & Seasonal & 11.3 & Se-11.3 \\
\hline $\begin{array}{l}\text { Spider (including } \\
\text { all four arms) }\end{array}$ & Seasonal & 11.3 & Se-11.3 \\
\hline
\end{tabular}

The Greater Addo Elephant National Park (GAENP) freshwater study identified and described four freshwater processes of importance (see Forman 1995, Ward 1998, Barber-James et al. 2002), namely:

- hydrological regimes, which include the magnitude, frequency, duration, timing, and rate of change in water flow. These components interact to maintain the dynamics of in-channel and riparian habitats and determine the distribution of freshwater and riparian species. Natural disturbances, such as droughts and floods, are particularly important for maintaining the geomorphological integrity of freshwater ecosystems;

- nutrient cycling, or the process whereby elements such as nitrogen, phosphorus, and carbon move through an ecosystem. Reduction or augmentation of nutrients can alter the trophic status of freshwater ecosystems, which influences primary and secondary productivity and, as a result, overall ecological integrity. Riparian zones are particularly important because these areas serve as allochthonous sources of organic matter, filter sediment, and nutrient inputs from terrestrial ecosystems;

- migration. Connectivity, over both space and time, is needed for the movement of species (migration) between habitats. Longitudinal connectivity allows biota to move up and down the catchment, for example, to complete their life cycles. Continuity in riparian corridors is necessary to allow migration of terrestrial species, such as otters, and distribution of flora. Local-scale movement of species is especially important during times of habitat change or climatic disruptions, for instance, movement into refuge areas to survive during floods, droughts, or the dry season. Riparian vegetation serves as a refuge for the adult aerial stage of aquatic insects and is therefore an important component for ensuring the successful completion of their life cycles; and

- succession and evolution. River systems are longitudinal systems, meaning that most fish and some invertebrate species are restricted to a particular river system and as such are isolated from other populations in adjacent rivers. The evolutionary processes acting on species inhabiting perennial rivers (e.g., the Wit River) would therefore be very different from those acting on species found in intermittent rivers (e.g., the Uie River). In addition, patterns of faunal assemblages in 
temporary water ecosystems are established by colonizer or pioneering species on a "first come, first served" basis. It is important to recognize this as a process that sets a particular pattern. Two adjacent pools in a river may each have an entirely different complement of occupying species. The only notable difference will be that the succession of colonizer species from outside differed for each pool, resulting in different species assemblages.

\section{QUANTITATIVE CONSERVATION TARGETS}

In terrestrial conservation planning, targets such as $10 \%$ of a country's area or $20 \%$ of each vegetation type are often applied. The Caring for the Earth strategy (IUCN 1989) set a target for conservation of at least $10 \%$ of each biome or habitat type. Despite the inevitable arbitrariness and subjectivity in their formulation, the value of such targets is that they are explicit. Resource managers need to know what they should be aiming for, even if their goal is based on best current knowledge and expert judgment (Margules and Pressey 2000).

Important considerations in the development of targets for conserving river biodiversity in the Greater Addo Elephant National Park (GAENP) were that:

- the river signatures concept provided a means of targeting biodiversity pattern in terms of representation;

- rivers are continuous ecological units, and conservation of their lower reaches is largely dependent on the conservation of reaches further upstream. Selecting discontinuous representative segments of a river based on cadastral boundaries is therefore not appropriate for the conservation of river ecosystems. For this reason, whole river lengths were selected for inclusion in the conservation plan;

- the key ecosystem processes identified are all, to some extent, maintained by longitudinal continuity. Given that river communities represent a continuum, an anthropogenic disturbance, such as excessive abstraction or construction of a dam, creates a discontinuity. A certain distance downstream from the disturbance is needed for the river to recover from the effects of the disturbance. The serial discontinuity concept (Ward and Stanford 1983) builds directly on the river continuum concept (Vannote et al. 1980) and provides further justification for selecting whole rivers as the minimum biodiversity feature to be conserved; and

- the river signatures cater to landscape and longitudinal patterns, but not to lateral patterns. It is recognized that riparian zones and fringing floodplains form an integral part of a river ecosystem and contribute functionally to the overall integrity of these systems (see Ward 1998). Riparian zones are important in maintaining ecosystem processes and, in particular, nutrient cycling and lateral migration.

The following explicit targets were formulated for the conservation of biodiversity patterns and processes for the rivers and streams within the GAENP planning domain:

- the conservation of at least one river within each unique Level 2 signature of physical pattern (Table 2). This target aims to conserve a representative spectrum of biodiversity patterns. Additionally, because the whole river is selected, important biological processes are maintained as well; and

- riparian buffer strips at least $500 \mathrm{~m}$ wide on either side of the rivers and streams that are selected under the first target. This 500-m width is an estimate of the area that would ensure sufficient protection of lateral patterns of rivers and is based on expert judgment. This target also recognizes that land is not acquired per catchment but per land tenure parcel. In instances where it is impractical to acquire a whole catchment, priority should be given to land parcels that incorporate the specified riparian buffer width.

\section{PRIORITIES FOR ACHIEVING CONSERVATION TARGETS}

Strategic conservation planning hinges on the identification of different options for conservation that will meet the set biodiversity targets. When two or more rivers have the same signature and it becomes necessary to choose between them, a number of considerations could be used to assist in making decisions of this type. For the purposes of this study, the following factors were considered: 
- the extent of transformation,

- the degree of inclusion within the park,

- irreplaceability as a measure of uniqueness, and

- the geomorphological diversity of rivers.

\section{Extent of transformation}

Extent of transformation is related to the concept of "the present ecological state or status" that is widely used by aquatic scientists in South Africa. This concept essentially refers to the degree of modification in relation to the ecological integrity of river ecosystems. Various biological and habitat indices have been developed for assessing the in-stream and riparian integrity of rivers (Roux 1999), and several integrity classification schemes have been used to express the present ecological state or extent of transformation (e.g., Kleynhans 1996 and Water Research Commission 2001).

The scope of this project did not allow for a quantitative assessment of the extent of the transformation of freshwater ecosystems. Instead, a desktop estimation was made based on expert judgment and guided by spatial data for land cover, land use activities, and infestation by alien plants, as well as knowledge of flow modifications. In line with the approach followed by the terrestrial conservation study, three transformation categories were used, and weights were allocated as follows: intact (insignificant transformation) $=3$, restorable (moderate transformation) $=2$, and transformed (ecosystem changed to new equilibrium $)=1$.

\section{Degree of inclusion within park}

Impacts on river integrity and biodiversity are cumulative. Although it would be ideal to include whole river systems in a formal reserve, the longitudinal character of rivers poses a challenge to achieving whole river conservation. Where conservation options exist between two or more rivers that theoretically represent the same biodiversity pattern, it makes sense to select the system with potentially the largest proportional section within a formal conservation area. As such, weights were allocated to rivers as follows: entirely included in planning domain $=3$, most of upper reaches included in planning domain $=2$, and mostly only lower reaches fall within planning domain $=1$.

\section{Irreplaceability or uniqueness}

Irreplaceability is used as a measure of uniqueness and reflects the importance of a specific river, in the context of the planning domain, in achieving conservation targets (Ferrier et al. 2000). Where a specific river signature or biodiversity pattern is represented by a single river, that river has a high irreplaceability. Consequently, it must be conserved if the conservation targets are to be achieved. Rivers with lower conservation scores do not necessarily have lower conservation value; lower scores simply mean that planners have more flexibility when it comes to reaching conservation targets. Weights were allocated as follows: one river per signature $=3$, two rivers per signature $=2$, and more than two rivers per signature $=$ 1.

\section{Geomorphological diversity}

Geomorphological zones were used as a measure of longitudinal river patterns in constructing Level 3 river signatures. For the purpose of assigning priorities to conservation options, geomorphological diversity weightings are used to indicate whether a river is more or less diverse in terms of geomorphological zones. Weightings are allocated as follows: four or more zones $=3$, three zones $=2$, and two or one zone $=1$.

\section{Outcome}

Weightings for each of the above factors were summed to give an overall score for the conservation priority of each river (Table 4). Based on these relative priorities, the most appropriate rivers to be conserved (based on Level 2 signatures) were identified (Table 5 ). If the rivers within the same signature grouping still had the same weight, the selection reverted to the reserve design and implementation process. Here, issues such as overlap with terrestrial targets and practicalities of land acquisition would be determining factors.

One outcome of the study is that 16 of the 31 rivers considered had to be conserved to achieve adequate representation of the biodiversity patterns identified. Based on ecosystem processes, the Diep Kloof River and a river we called the Spider (the name is given in italics to indicate that it was assigned only for the purposes of this study) were granted "indemnity" status because of their endorheic characters, so that these rivers plus an additional river from their respective signature groups were automatically 
selected. The Diep Kloof and the Spider are not connected by a drainage network to the ocean, which has resulted in their relative isolation and given them the potential for unique evolutionary trajectories. The same type of indemnity would have been extended to the Sundays and Boknes Rivers because of their importance in connecting freshwater with estuarine and marine environments and associated maintenance of migratory processes. However, these rivers were automatically chosen because they were the only representatives of their respective signatures, so that indemnity was unnecessary.

Table 4. Relative conservation priorities for rivers of the Greater Addo Elephant National Park, where higher weights indicate higher priority. The overall conservation priority is a summation of the weights allocated to the four factors considered. River names in italics were assigned for the purposes of this study, because no official names for these rivers could be found. EOT = extent of transformation, DIWP = degree of inclusion within park, $\mathrm{U}=$ uniqueness, and GD = geomorphic diversity.

Weights given to conservation factors

\begin{tabular}{|c|c|c|c|c|c|}
\hline \multirow[b]{2}{*}{ River name } & \multirow[b]{2}{*}{ EOT } & & \multirow[b]{2}{*}{$\begin{array}{c}\text { Conservation } \\
\text { priority }\end{array}$} \\
\hline & & DIWP & $\mathrm{U}$ & GD & \\
\hline Wortelkuil & 3 & 3 & 1 & 3 & 10 \\
\hline Wortelkuil E1 & 3 & 3 & 1 & 3 & 10 \\
\hline Wortelkuil E2 & 3 & 3 & 1 & 2 & 9 \\
\hline Gwaasleegte & 3 & 3 & 1 & 2 & 9 \\
\hline Driekop & 2 & 1 & 1 & 1 & 5 \\
\hline Voël & 1 & 1 & 1 & 1 & 4 \\
\hline Brak N. & 3 & 1 & 1 & 1 & 5 \\
\hline Riet & 1 & 1 & 1 & 1 & 4 \\
\hline Volkers & 3 & 3 & 2 & 3 & 11 \\
\hline Volkers $S$ & 3 & 3 & 2 & 1 & 9 \\
\hline Bushmans & 2 & 2 & 3 & 2 & 9 \\
\hline Blou & 2 & 3 & 3 & 2 & 10 \\
\hline Steins & 2 & 2 & 3 & 2 & 10 \\
\hline Volkers & 3 & 3 & 2 & 3 & 11 \\
\hline Region 12 & 2 & 2 & 3 & 2 & 9 \\
\hline Kariega N. & 2 & 2 & 3 & 2 & 9 \\
\hline $\begin{array}{l}\text { Uie (including } \\
\text { Klein and Groot Uie) }\end{array}$ & 1 & 3 & 3 & 3 & 10 \\
\hline
\end{tabular}




\begin{tabular}{|c|c|c|c|c|c|}
\hline Krom & 2 & 3 & 3 & 3 & 11 \\
\hline Kabouga & 3 & 3 & 3 & 3 & 12 \\
\hline $\begin{array}{l}\text { Wit (including Wit } \\
\text { W1 and Wit W2) }\end{array}$ & 2 & 3 & 3 & 3 & 11 \\
\hline Courney & 2 & 3 & 3 & 3 & 11 \\
\hline Courney E1 & 2 & 3 & 2 & 3 & 10 \\
\hline Courney E2 & 2 & 3 & 2 & 2 & 9 \\
\hline Sundays & 1 & 1 & 3 & 2 & 7 \\
\hline Sundays Trib & 2 & 3 & 2 & 3 & 10 \\
\hline Groot Kloof & 2 & 3 & 2 & 3 & 10 \\
\hline Diep Kloof & 2 & 3 & 3 & 2 & 10 \\
\hline Boknes & 1 & 2 & 3 & 1 & 7 \\
\hline Bega & 2 & 2 & 1 & 2 & 7 \\
\hline Brak S. & 2 & 3 & 1 & 1 & 7 \\
\hline Nankoostroom & 2 & 3 & 1 & 1 & 7 \\
\hline $\begin{array}{l}\text { Spider (including } \\
\text { all four arms) }\end{array}$ & 2 & 3 & 3 & 2 & \\
\hline
\end{tabular}

With the addition of a river from signature 14 (other than the Diep Kloof) and a river from signature 16 (other than the Spider), the total number of rivers to be conserved increased to 18 . Theoretically, these 18 rivers represent the riverine biodiversity of the Greater Addo Elephant National Park planning domain.

\section{DISCUSSION}

The river signature concept was developed specifically for this study, and the appropriateness of its different hierarchical levels has not been tested or verified with data and outcomes for other geographic areas. Given that the climatic and geophysical diversity across the Greater Addo Elephant National Park (GAENP) is enormous, the relatively high number of unique river signatures produced by both Level 2 and Level 3 signatures in this study, 16 and 31 respectively, is not surprising. Kerley and Boshoff (1997) referred to the proposed GAENP as " ... the most diverse conservation area in South Africa, and probably in the world."

There is considerable scope for the further development of river signatures as surrogates for biodiversity in freshwater ecosystems. Development activities should include testing and verification of the current approach, expansion of the signatures to include further river features (for example, lateral landscape and flow patterns such as floodplains and wetlands), refinement of target setting, and formalization of the integration of ecosystem processes into conservation targets. These signatures could be refined by incorporating actual mean annual runoff and monthly simulated flow data into assessments of river flow patterns. In addition, this 
paper does not address the integration of freshwater and terrestrial information, because that was a separate process in the overall project. The integration of freshwater and terrestrial biodiversity patterns and typology could be a subject of future research.

Table 5. Rivers to be conserved based on Level 2 signatures and the conservation priorities allocated in Table 4, where the river with the highest conservation priority within each signature group was selected. River names in italics were assigned for the purposes of this study because no official names for these rivers could be found.

\begin{tabular}{lccc}
\hline River name & $\begin{array}{c}\text { Level 2 } \\
\text { signature }\end{array}$ & $\begin{array}{c}\text { Conservation } \\
\text { priority }\end{array}$ & Rivers to be conserved \\
\hline
\end{tabular}

Wortelkuil

1

10

10

Wortelkuil E1

Wortelkuil E2

Gwaasleegte

Driekop

Voël

Brak N.

Riet

Volkers

Volkers S.

Bushmans

Blou

Steins

Region 12

Kariega N.

Uie (including Klein

and Groot Uie)

Krom

Kabouga

Wit (including Wit W1 and Wit W2)
2

3

7

9

9

5

4

5

5

11

Volkers

9

9

Bushmans

4

10

Blou

Steins

Region 12

Kariega N.

Uie (including Klein and Groot Uie)

Krom

Kabouga

Wit (including Wit

W1 and Wit W2) 


$\begin{array}{lccc}\text { Courney } & 11 & 11 & \text { Courney } \\ \text { Courney E1 } & 12 & 10 & \text { Courney E1 }\end{array}$

Sundays

One of Sundays Trib, Groot Kloof, or Diep Kloof

Groot Kloof

Diep Kloof

Boknes

Boknes

Bega

Spider

Brak S.

Although these findings are preliminary, we believe that the river signature concept as developed in this study holds promise for elevating the importance of aquatic biodiversity in rivers in conservation planning exercises. This approach has also made it possible to combine aquatic information with terrestrial information to achieve a more holistic approach for management decisions in the expansion of the GAENP.

Responses to this article can be read online at: http://www.consecol.org/vol6/iss2/art6/responses/index.html.

\section{Acknowledgments:}

Jeanne Nel, Inge Kotze, Brian van Wilgen, and Rob Palmer are thanked for sharing their insights during various stages of the study. Richard Cowling provided valuable technical guidance. Dineke Vink prepared the figures. Guy Castley is thanked for piloting the aircraft during the aerial survey and for help with the aerial photographic records. Gillian Maree provided editorial assistance. The Directorate of Museums and Heritage Resources, Eastern Cape Province, is thanked for providing research facilities and encouraging this study. Global Environment Facility (GEF), SANParks, and Mike Knight are thanked for opening the window of opportunity for this work to be done. We are grateful for the constructive and valuable comments provided by three anonymous reviewers.

\section{LITERATURE CITED}

Barber-James, H. M., J. A. Cambray, F. C. de Moor F. C., and D. J. Roux. 2002. Preliminary survey and desktop approach to conservation planning of freshwater ecosystems in the Greater Addo Elephant National Park (GEANP). CSIR Report, Number ENV-S-C 2002-002. CSIR Environmentek, Stellenbosch, South Africa.

Cowling, R. M. and R. L. Pressey. 2001. Rapid plant diversification: planning for an evolutionary future. Proceedings of the National Academy of Sciences of the United States of America 98 (10):5452-5457.

Department of Water Affairs and Forestry. 1999. Resource directed measures for protection of water resources. Volume 3. River ecosystems, version 1.0. Department of Water Affairs and Forestry, Pretoria, South Africa. online 
http://www.wrc.org.za/wrcrdm/wrcrivers/default.htm.

Ferrier, S., R. L. Pressey, and T. W. Barrett. 2000. A new predictor of the irreplaceability of areas for achieving a conservation goal, its application for real-world planning and a research agenda for further refinement. Biological Conservation 93:303-325.

Forman, R. T. T. 1995. Stream and river corridors. Chapter 7 in R. T. T. Forman. Land mosaics: the ecology of landscapes and regions. Cambridge University Press, Cambridge, UK.

Gordon, N. D., T. A. McMahon, and B. L. Finlayson. 1992. Stream hydrology: an introduction for ecologists. John Wiley, Chichester, UK.

IUCN. 1989. Caring for the Earth: a strategy for sustainable living. IUCN-The World Conservation Union, UNEP, and WWF-World Wide Fund for Nature, Gland, Switzerland. Available online at: http://coombs.anu.edu.au/ vern/caring/caring.html.

Kerley, G. I. H., and A. F. Boshoff. 1997. A proposal for a Greater Addo National Park - a regional and national conservation and development opportunity. Terrestrial Ecology Research Unit Report, Number 17. University of Port Elizabeth, Port Elizabeth, South Africa.

Kleynhans, C. J. 1996. A qualitative procedure for the assessment of the habitat integrity status of the Luvuvhu River (Limpopo System, South Africa). Journal of Aquatic Ecosystem Health 5:1-14.

Low, A. B., and A. G. Rebelo. 1996. Vegetation of South Africa, Lesotho and Swaziland. Department of Environmental Affairs and Tourism, Pretoria, South Africa.

Margules, C. R., and R. L. Pressey. 2000. Systematic conservation planning. Nature 405:243-253.

Omernik, J. M. 1987. Ecoregions of the conterminous United States. Annals of the Association of American Geographers 77:118-125.

Poiani, K. A., B. Richter, M. G. Anderson, and H. E. Richter. 2000. Biodiversity conservation at multiple scales: functional sites, landscapes, and networks. BioScience 50(2):133-146.

Roux, D. J. 1999. Design of a National Programme for Monitoring and Assessing the Health of Aquatic Ecosystems, with specific reference to the South African River Health Programme. Pages 13-32 in A. Gerhardt, editor. Biomonitoring of polluted water: reviews on actual topics. Trans Tech, Uetikon-Zurich, Switzerland.

Rowntree, K. M., and R. A. Wadeson. 2000. Field manual for channel classification and condition assessment. River Health Programme Report, Number 13. Institute for Water Quality Studies, Department of Water Affairs and Forestry, Pretoria, South Africa.
Rutherford, M. C., and R. H. Westfall. 1994. Biomes of southern Africa: an objective categorization. Memoirs of the Botanical Survey of South Africa 63:1-94.

Southwood, T. R. E. 1977. Habitat, the template for ecological strategies. Journal of Animal Ecology 46:337365 .

Stanford, J. A. 1998. Rivers in the landscape: introduction to the special issue on riparian and groundwater ecology. Freshwater Biology 40:402-406.

Vannote, R. L., G. W. Minshall, K. W. Cummins, J. R. Sedell, and C. E. Cushing. 1980. The river continuum concept. Canadian Journal of Fisheries and Aquatic Sciences 37:130-137.

Ward, J. V. 1998. Riverine landscapes: biodiversity patterns, disturbance regimes, and aquatic conservation. Biological Conservation 83 (3):269-278.

Ward, J. V., and J. A. Stanford. 1983. The serial discontinuity concept of lotic ecosystems. Pages 29-42 in T. D. Fontaine and S. M. Bartell, editors. Dynamics of lotic ecosystems. Ann Arbor Science, Ann Arbor, Michigan, USA.

Ward, R. C. 1975. Principles of hydrology. Second edition. McGraw-Hill, London, UK.

Water Research Commission. 2001. State of Rivers Report: Letaba and Luvuvhu River systems. WRC Report, Number TT 165/01. Water Research Commission, Pretoria, South Africa. 